\title{
Southern Strategies: Preaching, Prejudice, and Power
}

\author{
Angelia R. Wilson
}

This paper considers how 'preaching prejudice' builds a constituency of like-minds by marginalizing others - on grounds of race and sexuality, for example - and then instructs this constituency regarding political behavior. This discussion is part of a larger project on the construction of social values for political gain but here I specifically draw attention to the historical racism marking much of Protestant messaging in the American South and to how this racism became the foundation for the Republican Southern Strategy from the 1970s onwards. In doing so, I take as a case study the well documented racism associated with the history of the Southern Baptist Convention. The SBC historical narrative exemplifies the racism which underpinned the Southern Strategy. This is interesting because the SBC continues to be a key political actor among social conservatives in the South. This historical narrative indicates how 'preaching prejudice' became a political tool fueling the racism of Nixon's campaign and seasoning subsequent campaigns. The paper then suggests that the most recent innovation of this familiar, well honed political tool can be located in contemporary discourse on same-sex marriage.

\section{Nixon's Southern Strategy}

During the American Civil War, the Republican Party had been antislavery; unsurprisingly then, most postbellum white Southerners were Democrat. By the end of World War II, however, white Southerners became dissatisfied with Truman's plan, To Secure These Rights, which endorsed racial equality in employment, voting rights and desegregation in the armed forces. Some, 'Dixiecrats,' made various attempts at supporting third party candidates but, after defeat, returned to the fold of the Democratic Party. According to historian Dan Carter (in Anderson 1998, A1), it was the race-fueled campaign of independent candidate George Wallace who "laid the foundation for the dominance of the Republican Party in American society through the manipulation of racial and social issues in the 1960s and 1970s."1 Political historian Merle Black marks the speed with which Southern voters, finding a viable alternative, shifted allegiances: "in 1952 the South was the most important example of a one-party political system in the United States: the Democratic Party claimed $77 \%$ of southern voters," however, by the end of the $1960 \mathrm{~s}$, "fewer than $60 \%$ of southern voters were Democrat" and, in 2002, "Democrats claimed only 36\% of the region's voters" $(2004,1004)$. The key to this political realignment was the Republican Party's Southern Strategy to build upon post-Kennedy, civil rights discontentment and lure

ANGELIA R. WILSON is Senior Lecturer for the School of Social Sciences, The University of Manchester; Manchester, United Kingdom.

The American Review of Politics, Vol. 34, Winter, 2013-2014: 299-316

(C)2013 The American Review of Politics 
Southerners to support Nixon. In order to win the presidency, Nixon needed the Southern white vote. Frank Brown (2004) notes that Nixon's school choice policies, opposition to desegregation, and unwillingness to uphold the Supreme Court decision in Brown v. Board of Education were fundamental planks in his strategy. Nixon's win in 1972 was "the most overwhelming southern white vote- $79 \%$ - ever won by a Republican presidential candidate" (Black and Black 1992, 305).

On May 17, 1970, New York Times journalist James Boyd penned an article about a then unknown Republican political strategist named Kevin Phillips. Boyd offered up Phillips as the master mind of "Nixon's Southern Strategy." According to him, white Southern voters, alienated from the Northern base of the Democratic Party by the 1964 Civil Rights Act, were looking for a new political home. Moreover, the erosion of hostility toward Yankee Republicans that had inspired Southern Irish, Italian and Eastern European immigrants to be Democrats had now "shifted among their children and grand children to resentment of the new immigrants-Negroes and Latinos" and the Democratic Party whose policies tended to favor new immigrants over the old (Boyd 1970). Phillips' analysis of ethnic shifts across every state, and most individual counties, in his book, The Emerging Republican Majority, landed him a place on the Nixon campaign staff. His thesis was simple: "political success goes to the party that can cohesively hold together the largest number of ethnic prejudices" (Boyd 1970).

In brief, he argued, Republicans needed the white vote, not the black vote. In order for Nixon, and other Republicans to win, they "are never going to get more than $10-20 \%$ of the Negro vote and they don't need any more than that" (Boyd 1970). Furthermore, the more "Negros who register as Democrats," the more "whites will quit the Democratic Party and become Republicans" (Boyd 1970). He observed that "when the average voter steps into the booth he registers the prejudice or allegiance bred by a mix of geography, history and ethnic reaction which stems from a past he knows only murkily." Despite being publicly eviscerated by some in the Republican Party after the publication of Boyd's article, history attests to Phillips' demographic analysis and his electoral strategy correctly predicted the seismic shift of the Southern white vote to the Republican Party.

Interestingly in the same 1970 article, Phillips warned about a potential for "fascism": "the popular conservative majority now taking shape ... with its important component of military, apprehensive bourgeois and law-andorder-seeking individuals ... there is a proclivity toward authoritarianism and over-reaction to the liberal engendered permissiveness and anarchy of the sixties" (Boyd 1970). Phillips predicted that current trends would run their course and be "displaced by a new cycle whose origins are already with us, 
somewhere." That "somewhere" turned out to be the cultural revolutiona revolution that became the "culture war."

The story of the Southern Strategy did not begin with Kevin Phillips, nor in the aftermath of civil upheaval of the 1960s. The South had been marked for centuries as a place where the politics of othering engendered a sense of community: where those with power were well versed in rhetorical constructions of racial and moral difference which simultaneously erected an 'enemy' and posited an image of the South as a homogenous 'constituency' of the morally righteous. ${ }^{2}$ Here, I offer an account of the Southern Strategy that locates it within a broader historical context, and in doing so, maps a singular historical narrative about power and prejudice which continues to be articulated from Southern evangelical pulpits.

\section{Powerful Preaching}

Following the tradition of the Great Awakening, eighteenth century Methodist circuit riders and Baptist missionaries of Northern Reformed Protestantism migrated to the American South to spread the good news of the possibility of a personal relationship with Jesus Christ. In the process of sharing this gospel from the North to the South, ministers became aware of cultural differences and began to articulate the gospel in a language and cadence that appealed to potential converts. For example, historians (Snay 1989; McKivigan and Snay 1998; Harvey 1998; Smith 1997) agree that evangelical missionaries articulated the gospel with language that justified slavery and glorified Southern culture. Nixon's political strategist now turned historian of what he labels American Theocracy, Kevin Phillips (2006, 109) notes that: "Before the Baptists and Methodists could make evangelical religion dominate below the Mason-Dixon Line, they had toand did-shed notions that were perceived as radical, such as opposition to slavery and enmity to social hierarchies.",

A half-century later, many mainline Protestant denominations split over the issue of slavery only to reunite during Reconstruction. However, the Southern Baptists, unable to endorse principles of racial equality, rejected the possibility of reconciliation with their Northern counterparts. The resulting Southern Baptist Convention (SBC) has come to represent the core of evangelical voters and, in turn, the ground troops of Republican politics (Guth et al. 2006; Lindsey and Hackett 2008). ${ }^{4}$ Historical accounts, such as Nancy Ammerman's Baptist Battles and Ellen Rosenburg's The Southern Baptists offer critical narratives about the development of SBC and its place in Southern culture and politics. In Religion and the American Civil War, Paul Harvey points to the role of Baptist preachers, who by the early 19th century were articulating a "Christian proslavery apologetic"-arguing, for 
example, that God would use slavery to teach superior people to care for inferiors entrusted to them and to bring the gospel to the heathen (1998, 169). Such views became an "unchallenged orthodoxy among white southern evangelicals" (Harvey 1998, 170). After the Civil War, the shame of defeat at the hands of the Yankees became a tribulation to be endured until God revealed his plan for the exultation of the South. Southern Baptists weaved together individual salvation and the conservation of the social order, so unlike Northern Protestant social reformers, they were certain God was on the side of the Confederacy. "Southern Baptists," writes Harvey, "preached the political ideology of white supremacy from the pulpit" (1998, 177). They constructed their position on slavery and Reconstruction as a battle between order and disorder, a defence of the natural order and religious liberty. ${ }^{5}$ Baptist leaders built a political constituency by calling upon church members to vote for politicians who would represent "the white man's interest" (Harvey 1998, 177). During Reconstruction, evangelicals as well as Southern politicians utilized Old Testament readings regarding the oppression of God's people as balm for the wounds of Southern pride. Despite occasional references to Christian slaves as 'brother' or 'sister,' "Southern Baptists never accepted African Americans as equals in their churches" (Harvey 1998, 170). As the SBC membership grew and as race remained a key component of Southern politics, this refusal solidified their political positioning as the voice of white Southern Christian politics.

By the turn of the century, the Southern Baptist Convention, as representatives of the white evangelical church, articulated a distinctive Southern identity: "we are a different people, a different blood, a different climate, a different character, different customs, and we have largely different work to do in this world" (Harvey 1998, 178). Their religious affiliation provided a shared sense of identity based on shared morality. Phillips describes SBC as the "state or "established' Church of the South" that "thrives on the evangelical link between cultural domination and pursuit of membership growth" (Phillips 2006, 157). Oram Smith, academic historian and now President of a Family Research Council organization in South Carolina, observes: "Eventually, the notion of a Christian or even Baptist religion becomes a civic religion, a mentality so biding that Southern Baptists begin to think of themselves as the cultural majority with the goal not of rejecting society (as some small, sect-like religious conservatives have done), but of absorbing it. In such a world, Baptist clergy and lay leadership have no interest in taking stands against Southern cultural norms. They are not motivated to oppose the cultural or appear unpatriotic about the region, for to a greater and greater extent, they are the culture, they are the region" (Smith 1997, 39).

Beliefs in Southern exceptionalism have deep roots in religious justifications of slavery and postbellum rhetoric of a South that would 'rise again.' 
This "put a strong psychological imprint on its future" and in turn on the future of America (Phillips 2006, 150). As many Southerner pioneers and farmer-preachers pushed west, they took with them conservative religious values and evangelical missionary zeal. Southern pioneers believed "that the religious and political destiny of our nation is to be decided in the West" and hope to transform the wild frontier into a "Garden of the Lord," filled with churches and schools to provide for the West's moral, spiritual and civic health (PBS 2010). Commenting on this history, Phillips concludes that "by the 1830 s . . . evangelical Protestantism had won the soul count below the Mason-Dixon Line" and those settling in the West planted deep religious roots which have grown into the demographically traceable Southernization of the American West $(2006,167,170)$. Mark Shibley correlates the growth of Southern style religion across the U.S. directly with patterns of high levels of in-migration from the South in the late twentieth century (1991).

The patterns of regional spread of social conservative Christianity are significant politically as by the turn of the new century "religion was by far the strongest predictor" for Presidential electoral success (Norris and Inglehart 2004, 94). ${ }^{6}$ John Egerton's (1974) The Americanization of Dixie-published after Nixon's landslide in the South - pointed not just to the Americanization of the South, but importantly it called attention to the Southernization of American religion. ${ }^{7}$ Much of the terrain of America has experienced Southern migration, and as evangelical Christians have spread across the South and West, political discourse came to resonate with the tones of Southern Christianity and to suggest the foundations of 'red state' political culture.

\section{Political Preaching}

Conventional accounts of conservative Christian political involvement maintain that after the Scopes trial, humiliated fundamentalists and Biblical literalists stepped away from political activism. However, more contemporary histories document the growth and rise of cultural influence of fundamentalist, holiness, Pentecostal, and evangelical churches and organizations (Williams 2010). "From the 1940s-1960s - in decades when segregation and civil-rights demonstrations were roiling in the South-the SBC saw the number of its adherents nearly double from just over five million to just under ten million" (Phillips 2006, 154). ${ }^{8}$ Phillips observes that "evangelical, fundamentalist and Pentecostal religion far from evaporating or stagnating in backwater during the early twentieth century, seem to have been a gathering force, like an incoming tide" $(2006,115) .{ }^{9}$ Key to the historical narrative considered here is the expanding and maturing role of Southern evangelicals as political actors. 
In many ways, Nixon's Southern Strategy capitalized on an already growing friendship between politicians and Southern evangelicals. Rev. Billy Graham counselled every President from Eisenhower to Clinton (Williams 2010; Lindsey 2007). In endorsing the Eisenhower campaign, he expressed a deep connection with the vice-presidential candidate Nixon and considered him to be a "sincere" and "splendid churchman" (Williams 2010, 25). However, Graham's moderate approach to politics, and civil rights particularly, dissatisfied many Southern Christians. In the aftermath of Nixon's presidency, Southern evangelicals were disappointed and somewhat ambivalent about the Republican Party. The election of the Democratic candidate Jimmy Carter in 1976 attests that many were tempted by this Southern Baptist school teacher (Williams 2010, 126-27). But President Carter did not live up to expectation as a Christian conservative cultural warrior. By the early 1980s, Christian social conservatives established a strong footing in the public square from which to articulate their theopolitical message more professionally. The development of grassroots political strategies that could 'use the pews' informed work both inside the church walls as well as encouraged individual Christians to 'extend the pews' - to look beyond the isolated congregation and be more politically engaged.

Briefly, I want to draw attention to three identifiable tools of evangelicals and other Christian conservatives-"speakability," theo-political pedagogy, and activism as "parapublic institutions"-in order to foster insight about the role conservative Christians play in setting the frame of Southern, and possibly American, political discourse. These examples are but three aspects of, what William Connolly labels the "resonance machine" (Connolly 2008). First, "speakability" refers to the way in which issue framing enables those fluent in the discourse to participate in discussion but those unable, or unwilling, to speak with the same nuance or technicality are unheard or disempowered. ${ }^{10}$ As noted, the postbellum South sermons weaved together feelings of despair and defeat with the Old Testament message of tribulation before coming into the Kingdom of God. Southern clerics defined the relationship between religion and politics by translating the political conflict into religious terms (Snay 1993). Confederate defeat was constructed as part of a grand design that God was working out for his people- "we" will rise again. Literal Biblical interpretations framed the socio-political situation giving conservative Christians a particular language with which to interpret political events.

Similarly, with the contemporary cultural dominance of evangelicals in the South, and areas of Southernization, conservative Christians engage in political discourse framing it in Biblical tones. For example, references to "state's rights" have come to signify a postbellum condemnation of federal 
involvement in Southern affairs, e.g. desegregation, mandatory curriculum, welfare provision. Where white Southerners once had been largely a group of European immigrants needing and endorsing federal welfare programs as Democratic voters, with increasing numbers of Hispanic and AfricanAmericans Southern citizens having similar socio-economic needs, welfare came to be equated with handouts. ${ }^{11}$ Opposition to federal programs reiterated a Reformed Protestant theology of self-help and individual responsibility (Manow 2004). Arguments for state's rights are bound theologically to an individual responsibility to God-social programs undermine individual responsibility and therefore ones relationship to God (Phillips 2006, 168). In the backdrop of urban riots of the late 1960s, Nixon played upon a fear of African-Americans and of the overreach of the federal government. Calls for law and order, state rights and opposition to school desegregation and bussing were Nixon's dog-whistle politics (Greenburg 2007; Brown 2004). ${ }^{12}$ Even now, conservative Christian Republican presidential contenders, such as Rick Perry and Mike Huckabee, articulate support for "state's rights" and in doing so draw upon a theologically based rejection of federal interventions to combat racial discrimination.

The articulation of a political problem through religious moral codes also enables Republican politicians to appropriate issues in order to gain support of conservative Christians. For example, while it is common place for politicians to engage in 'dog-whistle politics,' in Tempting Faith, David Kuo, strategist for President George W. Bush, outlined exactly how "God Talk" enabled the political seduction of conservative Christian voters (2006). "God Talk" acts as a "surreptitious code inserted into their [politicians'] campaign speeches as a way to appeal to targeted evangelical voters without alienating non-evangelicals who were likely not to pick up on the code language" (Calfano et al. 2013). God Talk gives Republican politicians a speakability - coding and articulating political positions in a language accessible to conservative Christians and (intended to be) inaccessible to those not fluent in the discourse. Interpreting political moments through Biblical language was pioneered by Christian missionaries moving from North to South, honed by conservative Christian political actors since the Civil War and appropriated by contemporary Republican politicians reliant upon Southern Christian conservative votes.

Second, evangelicals are called to share a theological message and they have cultivated the professional production of this message from reprinting Bibles for Confederate soldiers to contemporary multi-media industrial complexes such as the Christian Broadcasting Network. In an impressive array of ways, and with significant financial support, evangelists such as Pat Robertson and publications such as Christianity Today provide spiritual direction and interpretations of political and cultural events for millions of 
Americans (Herman 1998; Maddux 2010). The National Religious Broadcasters, established in 1944, lobbied the FCC for less regulation and more airtime for religious programming. Now NRB brings together thousands of 'Christian Communicators' to "transform culture through the application of sound biblical teaching" (www.nrb.org). In 1974, Bill Bright, founder Campus Crusade for Christ, and John Conlan, sought to bring Christians into politics through Third Century Publishing which produced such books as In the Spirit of '76: The Citizen's Guide to Politics. Third Century Publishing was a "new awakening of evangelical political consciousness" (Williams $2010,122)$. Today, the most effective political outcome of this evangelical boom is the extensive distribution of Family Research Council 'voter guides' into every pulpit, pew and local congregation across America. ${ }^{13}$ Educating individual believers in political language and intervention techniques mirrors more highly sophisticated academic pursuits training young pastors, lawyers, politicians and lobbyists at Southern Christian institutions such as Bob Jones University and Liberty University.

Finally, in his research on church-state relations in Europe, Peter Katzenstein conceptualizes mainline churches not as interest groups but as "parapublic institutions" with a heightened status and investment in both public and private sectors $(1987,58-60)$. A similar duality of political privilege can be observed in U.S. church-state relations. For example, Joseph Gusfield's Symbolic Crusade outlines how the American temperance movement was one method by which abstinence from alcohol served as a symbol of white, Protestant cultural dominance over the increasingly multicultural and immigrant population of the United States in the post-World War I period (1963). ${ }^{14}$ Historian Mitchell Snay argues that since Reconstruction, Southern ministers have demanded to chart the political course when moral issues were at stake (Snay 1993). As I demonstrate elsewhere, contemporary examples of this can be evidenced in the theological and economic investment of defining and providing welfare (Norris and Inglehart 2004; Wilson 2013, 2009). As major stakeholders in the political economy of care, religious institutions frame political discussions regarding welfare in order to defend their investments in private/charitable provision of care.

Undoubtedly, those that employ these tools do not all sing from the same political or theological hymn sheet (Williams 2010; Lindsey 2007; Berlet 1995). Conflicts, differences and power struggles between individual elites, denominations and organizations mark the Christian Right (Dowland 2009). For example, while Billy Graham and the National Association of Evangelicals dined at the White House, fundamentalists such as Bob Jones, Jr., Jerry Falwell, and SBC elites differentiated themselves from Graham's ecumenical approach. In declaring the 'culture war,' most Christian conservative leaders acknowledged the need for, what Francis Schaeffer termed, 
a "co-belligerent politics," particularly on wedge issues such as abortion or homosexuality. Strategically targeted political alliances such as the Christian Coalition and the Moral Majority defined themselves through the use of these wedge issues against a shared political 'other,' broadly painted as secular culture.

Christianity Today executive editor and theologian, Timothy George (1997) described co-belligerency as "an ecumenism of the trenches." ${ }^{, 15}$ In his excellent history of the 'family values agenda,' Seth Dowland observes that key to recent co-belligerent activism was the construction of a 'majority' which they achieved "by convincing themselves that they represented a majority of Americans - and by convincing enough Americans that a liberal minority had launched a covert war on the family" $(2009,631)$. The cobelligerency strategy fuels coalitions developing between economic and social conservatives from Ronald Reagan's 'New Right' to the current Christian Right/Tea Party collation symbolized by Ralph Reed's 'Faith and Freedom' organization (Wilson and Burack 2012; Posner 2008). Cobelligerent politics is a rational, expedient choice to join forces temporarily to defeat a common enemy. While not a conspiracy of minds, but against enemies, the co-belligerent Christian Right now represents a significant political force setting the discursive frame of Republican, if not American, politics. $^{16}$

\section{Hollow Apologies and Renewed Southern Strategies}

Alongside the development and maturation of this resonance machine, however, it became politically untenable to appear racist. In 2005, RNC chairman, Ken Mehlman acknowledged the use of a Southern Strategy since 1968 and admitted that Republicans had used race as a wedge issue to win white Southern votes: "Some Republicans gave up on winning the AfricanAmerican vote, looking the other way or trying to benefit politically from racial polarization. ... I am here as Republican chairman to tell you we were wrong." In 2009, the RNC elected its first African-American chairperson, Michael Steele, and soon he, too, confirmed the use of the Southern Strategy: "For the last 40-plus years we had a 'Southern Strategy' that alienated many minority voters by focusing on the white male vote in the South. Well, guess what happened in 1992, folks, 'Bubba' went back home to the Democratic Party and voted for Bill Clinton." There are a number of observations to be made about these acknowledgments but perhaps the most obvious is that they are not apologies.

Additionally, it is interesting to note who exactly was thrust onto the public stage to articulate this message. Steele was not successful in securing a second term in 2011 largely due to scandals regarding his approval of 
excessive expenses for limos, private jets, a bondage themed nightclub and general incompetence. The media rhetoric surrounding Steele was about "spending," "sex scandals," "strip clubs" and portrayed him as "smug," "poor" at his job, "dumb," and "out of his league." Despite Steele's election to the RNC leadership, after two years of providing a welcoming image for potential Republican African-Americans, the campaign to move him out of office tapped into racist stereotypes about African-American men. Moreover, there is substantial evidence of racism with the overlapping constituencies of the Republican Party, the Christian Right and the Tea Party (Wilson and Burack 2012). Racism-manifest in the birther movement, references to President Obama as "aloof" and the First Lady as "uppity"continues to play a significant part in Republican and Christian Right discourse.

What has been noticeable over the last twenty years is the way in which the political tools used to marginalize, or 'other,' have been deployed against LGBT citizens. Antigay rhetoric has not replaced racism. However, the familiar political tool of preaching prejudice continues to ensure power in a more racial diversity - but overwhelmingly heterosexual-demographic. To begin to explore this point, consider the context of the 'apology' for the Southern Strategy. The original acknowledgement of the strategy was not articulated by an African-American man but by a white, middle aged, man working directly with President Bush: Ken Mehlman. Given his proximity to the President - and history as a manager of the Bush-Cheney reelection campaign - his words might have indicated a new direction in Republican politics (Herbert 2005). However, upon leaving his post, Mehlman identified himself as a gay man and thus enabled some to dismiss the 'apology' as not reflective of the desires of the Republican leadership. As someone who had worked alongside Karl Rove to place anti-gay initiatives on election ballots in 2004 and 2006, Mehlman was vilified by gay activists who despised that such a homophobic campaign had been "run by one of the nation's worst closeted individuals" (Bolcer 2011). Criticism also came from conservative Christians. Tony Perkins, president of the Family Research Council, clarified that Mehlman's coming out helped explain "the scandalous failure" of the Republican establishment to fight same-sex marriage (Zernike 2010). Robert Morrison, Senior Fellow for Policy Studies at the Family Research Council, challenged Mehlman's interpretation of the Southern Strategy stating that it was not about using racism but about ensuring "electoral votes in the Solid South" (Mantyla 2010 ).

Steele's and Mehlman's interventions suggest a strategic shift in framing. While one interpretation is that Republicans were signaling an end to using racism as a political strategy, I think this is an inaccurate reading of events. Racism, blatant or subtle, will continue to win significant numbers of 
white votes for Republican candidates, but, as noted below, the culture war has engendered an additional political 'other' with the potential to build and solidify a larger constituency of diverse conservative religious groups at a much smaller political cost or risk of alienating potential allies. Employing the tools now familiar to conservative Christian politics - speakability, theopolitical pedagogy and political activism inside and outside religious institutions - the resonance machine seems to have prioritized constructing 'gays' as political enemies threatening American life. That does not imply that racism has lessened as a constituency building tool. Instead it is to acknowledge that Republican politics at the turn of the 21 st Century (re-)launched a strategic attack on one group of American citizens and that their success in the South and other Southernized red states confirmed that, while some Republicans may articulate remorse for racist political strategies, most Republicans-conservative Christians, in particular-advocated an anti-gay political strategy. The emergence of this strategy can be traced historically and culminated in legislation 'defending' heterosexual marriage. Such a narrative, outlined below, is not entirely distinct from Nixon's Southern Strategy and can be seen as a development, a nuancing - a contemporary redeployment.

As the father of Nixon's Southern Strategy, Phillips emphasized the need to be aware of precisely how many votes are crucial and from which groups of people. Even in 2002, former advisor to Republican Presidents and one-time Presidential candidate Pat Buchanan acknowledged that the Southern Strategy worked-with Republicans continuing to take about 60 percent of the white vote and as long as this continues, few other votes are needed (2002). For some conservative Christians this may be unpalatable or given the continued growth of African-American and Hispanic evangelical churches/constituencies it may be politically undesirable. Even the leaders of tea party organizations recognize the need to move away from a racist image (FreedomWorks 2010; Wilson and Burack 2012). However, just as the socio-political credibility of a Southern Strategy based on racial prejudice began to wane, the Christian Right, and in turn the Republican Party, had constructed a more modern political enemy that has paid substantial political dividends in the South and Southernized U.S. The family values agenda with its roots, language and cultural cadence inspired conservative Christians to action most recently against same-sex marriage (SSM). Arguably, SSM is the jackpot of political issues: states rights, endless pedagogical potential based on Old Testament theology, a speakability across denominations and a culturally palatable enemy to ensure the long term political cohesion of conservative Christian community.

Since the early days of Falwell's Moral Majority, 'gay rights' has served as a rallying cry to conservative Christians. Anita Bryant's 1977 
campaign in Dade County against a measure prohibiting employment discrimination became a template for associating gay rights with some sort of risk to children and to the institution of the family. Theo-political discourse soon established gay rights as 'special rights' granted to minorities who threaten good Americans and interpreted HIV and AIDS as the manifestation of that threat. The Homosexual Agenda, writes Christian conservatives Alan Sears and Craig Osten, "whether you realized it or not ... affects your marriage, it threatens your children, and if we don't do something soon, it will drastically limit your religious liberty" $(2003,12)$. By 1992, Buchanan rallied the Christian grassroots of the Republican National Convention by declaring war: "There is a religious war going on in our country for the soul of America. It is a cultural war, as critical to the kind of nation we will one day be as was the Cold War itself." As Buchanan warned, the "struggle for the soul of America" was reaching a crescendo.

One year later, the Hawaii Supreme Court decision, Baehr v. Lewin, found it unconstitutional to deny gay and lesbian citizens the right to marriage. Conservative Christians constructed this decision as posing significant danger to the family and, before the appeal was heard in Baehr, anti-gay marriage legislation began to spring up in other states. The regulation of marriage had been traditionally the domain of the state government-an issue of states' rights. By September 1996 The Defense of Marriage Act had swept through Congress and was signed into law by President Clinton. As a pre-emptive strike, it sent a signal to states to not grant marriage licenses to same-sex couples. Completely at odds with the historical defence of states' rights, and in what Ball evidences as a "severe and harmful backlash," the threat of same-sex marriage warranted federal intervention to ensure that marriage remained exclusively heterosexual. Federal law could not recognize same-sex couples as married and any state doing so would have that decision 'contained' within its own borders $(2006,1494)$. Barry Adam notes that DOMA successfully repositioned gay men and lesbians as "the enemy of the common folk" $(2003,269)$.

In 2003, the Massachusetts Supreme Court decided, in Goodridge v. Department of Public Health, that same-sex couples should be allowed to marry and directed the legislation to make this possible. The state's Catholic Bishops issued a statement referring to the court's decision as "a national tragedy" (Ball 2006, 1501). In the same year, the U.S. Supreme Court struck down state sodomy laws, Lawrence v. Texas. Given the inability to 'protect' themselves through sodomy laws and the possibility that states might be forced to recognize same-sex marriages under 'full faith and credit,' conservative Christians across the U.S. supported state constitutional amendments defining marriage as only a relationship between a man and a woman. This "two-part strategy" first pushed for a federal amendment to take away 
power from the state to decide marriage regulations then pressed for state constitutional amendments banning same-sex marriage (Dao 2004; Leonard 2004).

The campaign against same-sex marriage, or more widely against gay and lesbian citizens, constructs homosexuality as a sin, as a threat to the family and to the nation. From Falwell famously blaming 'homosexuals' for the terrorists attacks of 9/11 to FRC directives in Culture Impact literature, the political discourse is framed to construct gay men and lesbians as 'other,' as a 'threat,' as un-American, and as a theologically clear 'enemy.' Those challenging such constructions with a language of civil rights or discrimination are rendered as threats themselves. For example, Family Research Council Culture Impact policy goals instruct evangelicals that homosexuality is a choice and therefore those who "misuse civil rights laws to protect homosexual conduct and gender identity disorder" are political enemies (Cureton 2011). Any other outcome would "mandate the employment of homosexuals in inappropriate occupations ... employers in the area of education and childcare would be required to hire homosexuals"; civil rights based legislations would "destroy employer's rights to set dress and grooming standards for their employees ... that is culturally appropriate for the employee's biological sex"; civil rights would "pave the way for legalization of counterfeit same-sex 'marriage' . . f forcing same-sex 'marriage' on every state in the union." $" 17$

According to the Family Research Council, evangelicals have "dual citizenship" and with "dual commissions"- - defined as the familiar "Great Commission" to spread the "Good News" and the more recently articulated "Cultural Commission" in which "God delegated the development of culture and society to humankind ... to overcome evil with good" which includes "exerting a positive influence on public policy and government." As parapublic political actors, evangelical Christians are to be engaged not just in lobbying government but in participating, leading and becoming government in order to ensure conservative Christian ideals are reflected in policy and law. The outcome of their efforts, and the wholesale endorsement of this rearticulated Southern Strategy by Republican politicians, is that 31 states have amendments defining marriage as between a man and a woman. Some have gone further than others. Including recent ballots in North Carolina, voters in 20 American states have ratified amendments to state constitutions banning recognition of all forms of relationship rights (i.e., marriage, civil unions, domestic partnerships, reciprocal benefits, etc.) for same-sex couples: Alabama, Arkansas, Florida, Georgia, Idaho, Kansas, Kentucky, Louisiana, Michigan, Nebraska, North Dakota, Ohio, Oklahoma, South Carolina, South Dakota, Texas, Utah, Virginia, and Wisconsin. ${ }^{18}$ 


\section{Conclusion}

The swift, professional, legal and cultural challenge in the wake of Baehr and Goodridge should not have been a surprise. Constituency building through a politics of othering has a long history in the Confederacy. ${ }^{19}$ Just as Phillips had pointed out in the late 1960s, political strategy is about "holding together the largest number of ethnic prejudices." Anti-gay prejudices hold together a large number, and in some states an overwhelming majority, of constituents. Just as Phillips acknowledged in the 1960s, and Buchanan restated in 2002, Republicans do not need the African-American vote. Likewise they do not need the gay vote. They are happy for Democrats to be seen as gay-friendly and to paint this as un-Christian or anti-religious freedom (Adam 2003, 274). ${ }^{20}$ These political tools have been honed over centuries of racism. They have become the tools not just of local preachers or Southern politicians but of a highly professional industry directed at a perceived cultural, political, and theological 'other.' In locating the resonance machine, Connolly focuses on the emergence of the New Right (2008). But the narrative and strategies deployed by conservative Christians draw upon a much deeper cultural history. As such, the political situation may be more historically entrenched, and more difficult to overcome, than imagined.

\section{NOTES}

${ }^{1}$ George Wallace, according to Carter, had been "the master teacher and Richard Nixon and the Republican leadership that followed were his students."

${ }^{2}$ Here I rely specifically on Norman Fairclough's (1989) analysis of how narratives about "the other" explicitly or implicitly construct narratives about "us/them" that create "perceptions of constituency" and "perceptions of enemies." See also Brewer (1999).

${ }^{3}$ Phillips reflections on the history of the Republican Party in relation to conservative Christianity is particularly of interest given his historical proximity to events.

${ }^{4}$ Phillips describes SBC "an eight-hundred-ton dinosaur in the parlor of American Protestantism, and over the last century the fastest-growing major church in the United States" $(2006,149)$.

${ }^{5}$ Mitchell Snay $(1993,11)$ concurs that Southern clerics "essentially translated the political conflict into religious terms."

${ }^{6}$ Also they note "committed evangelicals are far more likely to live in small towns or rural areas, especially in the Southern and Midwest."

${ }^{7}$ See also Gregory (1998).

${ }^{8}$ The SBC statement on the nation in 1968 led to enough controversy that slowed growth but by the 1990s surveys were showing growth in the west, and southern parts of mid-western states.

${ }^{9}$ Williams (2010) comments on the popularity of evangelist Billy Graham, particularly the involvement of media mogul William Randolf Hirst. Graham was careful not to 
identify as a fundamentalist but his popularity did pave the way for the growth of fundamentalism from 1920s to 1960 s.

${ }^{10}$ Davina Cooper employs this term to explain how examinations of "new modes of speakability" can enable one to identify "normative and epistemological practices" that set the parameters for political engagement. Such parameters include "the urge and capacity to speak, the extent to which a topic or field renders itself utterable, what can be legitimately said and a talent for speaking" (2006, 922-928).

${ }^{11}$ The racial othering within welfare policy discourse is a well-documented theme. See, for example, Hancock, 2004; Smith, 2007.

${ }^{12}$ Brown (2004) notes how from Nixon onwards Republican presidents use opposition to school desegregation as an important aspect of the Southern strategy. Given the perceived attack on (white) Southern culture in court decisions such as Scopes, Brown, and Bob Jones University v. United States, Southern evangelicals held the judiciary as suspect. Contemporary shorthand for this dissatisfaction is the denunciation of 'activist judges.'

${ }^{13}$ Through their CultureImpact.org, FRC instructs individuals and small groups in lobbying and campaign strategies providing resource packets complete with, among other things, high-spec bulletin inserts on abortion, homosexuality, voter registration, etc. http://downloads.frc.org/EF/EF11C74.pdf; The author has conducted participant observations of cultural impact training on two occasions at Values Voters Summit 2010 and 2008.

${ }^{14}$ Adam $(2003,270-72)$ adds that this is why equality rights became tainted as the refuge of the lazy, the "special" plea for favoritism among those who "can't cut it" on their own.

${ }^{15}$ In establishing the Moral Majority, Jerry Falwell was influenced tremendously by Schaeffer's call for conservative Protestants to work with Catholics on issue such as abortion.

${ }^{16}$ Reminding us that "the GOP was a minority party in the 1970s," Williams writes "in order to win, republicans had to siphon votes from the Democrats, and the Republicans' political strategists believed that a shift to the right on the social issues would be the easiest way to do that." In his assessment, "what began as a temporary political ploy quickly became irreversible" with the party increasingly controlled by the Christian Right (Williams 2010, 7).

${ }^{17}$ The section is followed by one announcing that "the institution of marriage is in crisis" and how by changing welfare and family law to discourage divorce and cohabitation, require counselling and "divorce reduction classes" to learn about "the harmful effects of divorce, relationship skills and the potential for reconciliation."

${ }^{18}$ Dan Pinello, CUNY law and politics professor explains the differences between mini-DOMAs and Super-DOMAs at http://www.danpinello.com/SuperDOMAs.htm.

${ }^{19}$ In the narrative constructed here, I do not claim that prejudice towards gay men and lesbians has taken the place of racism. American society continues to be marked by racism and expressions of racism changes over time, location and intensity. At this moment in U.S. history, expressions of anti-gay beliefs are acceptable, culturally resonant, and are being deployed to ensure continued political power. In addition, the framing of this political discourse is such that intersectional identities, e.g. African-American lesbian, are rendered, in Judith Butler's phrase, "unintelligible."

${ }^{20}$ Karl Rove made "marriage amendments a cornerstone of his get-out-the-evangelical-vote campaign" (Wildman 2004, 39). 


\section{REFERENCES}

Adam, Barry D. 2003. The Defense of Marriage Act and American Exceptionalism: The 'Gay Marriage' Panic in the United States. Journal of the History of Sexuality 12(2).

Anderson, John. 1998. Former governor shaped politics of Alabama, nation. The Huntsville Times, Huntsville, Alabama, September 14, pp. A1, A8.

Ball, Carlos A. 2006. The Backlash Thesis and Same-Sex Marriage: Learning from Brown v. Board of Education and Its Aftermath. Wm. \& Mary Bill of Rts. J. 14(4): 1493-1538.

Berlet, Chip, ed. 1995. Eyes Right! Boston, MA: South End Press.

Black, Earl, and Merle Black. 1992. The Vital South. Cambridge, MA: Harvard University Press.

Black, Merle. 2004. The Transformation of the Southern Democratic Party. The Journal of Politics 66(4):1001-1017.

Bolcer, Julie. 2011. Mehlman Lobbies for New York Marriage. The Advocate, July 7, http://www.advocate.com/News/Daily_News/2011/06/07/Mehlman_Lobbies_for New York Marriage/.

Boyd, James. 1970. Nixon's Southern strategy. The New York Times, pp. 25, 105-106.

Brewer, Marilynn. 1999. The Psychology of Prejudice: Ingroup Love or Outgroup Hate? Journal of Social Issues 55(3):429-444.

Brown, Frank. 2004. Nixon's 'Southern Strategy' and Forces against Brown. The Journal of Negro Education 73(3):190-208.

Buchanan, P. 1992, Speech can be accessed at http://buchanan.org/blog/1992-republicannational-convention-speech-148.

Buchanan, P. 2002. The Death of the West. New York: St. Martin's Press.

Calfano, Brian R., Paul A. Djupe, and Angelia R. Wilson. 2013. God Talk in the UK. Politics and Religion.

Connolly, William. 2008. Capitalism and Christianity, American Style. Durham, NC: Duke University Press.

Cooper, Davina. 2006. Active Citizenship and the Governmentality of Local Lesbian and Gay Politics. Political Geography 25:921-943.

Cureton, Kenyn. 2011. The Culture Impact Team Resource Manual. Washington DC: Family Research Council.

Dao, James. 2004. State Action Is Pursued on Same-Sex Marriage, New York Times, February 27, p. A24.

Dowland, Seth. 2009. 'Family Values' and the Formation of a Christian Right Agenda. Church History 78(3):606-631.

Egerton, John. 1974. The Americanization of Dixie: The Southernization of America. Harper's Magazine.

Evangelicals and Catholics Together. 1994. http://www.firstthings.com/article/2007/01/ evangelicals--catholics-together-the-christian-mission-in-the-third-millennium-2.

Fairclough, Norman. 1989. Language and Power. London: Longman.

FreedomWorks, 2010 Press Release, July 14. http://www.freedomworks.org/pressreleases/freedomworks-responds-to-naacp-allegations-of-raci, accessed January 7, 2011.

George, Timothy. 1997. Evangelicals and Catholics Together: A New Initiative. Christianity Today http://www.christianitytoday.com/ct/1997/december8/7te034.html. 
Greenburg, David. 2007. Dog-Whistling Dixie. Slate, November. http://www.slate.com/ articles/news and politics/history lesson/2007/11/dogwhistling_dixie.html.

Gregory, James. 1998. Southernizing the American Working Class. Labor History $39(2): 135-154$.

Gusfield, Joseph. 1963. Symbolic Crusade. Urbana: University of Illinois Press.

Guth, J.L., L.A. Kellstedt, C.E. Smidt, and J.C. Green. 2006. Religious Influences in the 2004 Presidential Election. Presidential Studies Quarterly 36:223-242.

Hancock, A.M. 2004. The Politics of Disgust. New York: New York University Press.

Harvey, Paul. 1998. 'Yankee Faith' and Southern Redemption. In Religion and the American Civil War, eds. Randall M. Miller, Harry S. Stout, and Charles Reagan Wilson. Oxford: Oxford University Press.

Herbert, Bob. 2005. An empty Apology. New York Times, July 18, http://www.nytimes. com/2005/07/18/opinion/18herbert.html.

Herman, Didi. 1998. The Antigay Agenda: Orthodox Vision and the Christian Right. Chicago: University of Chicago Press.

Katzenstein, P.J. 1987. Policy and Politics in West Germany: The Growth of a Semisovereign State. Philadelphia: Temple University Press.

Kuo, David. 2006. Tempting Faith: An Inside Story of Political Seduction. New York: Free Press.

Leonard, Mary. 2004. SJC Ruling Aftermath: Mass. Rulings Push States to Seek a Ban. Boston Globe, February 7.

Lindsey, D.M. 2007. Faith in the Halls of Power. Oxford: Oxford University Press.

Lindsey, D.M., and C. Hackett. 2008. Measuring Evangelicalism: Consequences of Different Operationalization Strategies. Journal for the Scientific Study of Religion 47(3):499-514.

Maddux, Kirsty. 2010. The Faithful Citizen. Waco, TX: Baylor University Press.

Manow, P. 2004. The Good, the Bad, and the Ugly: Esping-Andersen's Regime Typology and the Religious Roots of the Western Welfare State. MPIfG Working Paper 04/3. Max-Planck-Institut für Gesellschaftsforschung, Köln.

Mantyla, Kyle. 2010. FRC Defends Southern Strategy as Just How You Win Votes in the South. People for the American Way, http://www.rightwingwatch.org/content/frcdefends-use-southern-strategy-completely-redefining-it.

McKivigan, J., and Mitchell Snay, eds. 1998. Religion and the Antebellum Debate over Slavery. Athens: University of Georgia Press.

Norris, P., and R. Inglehart. 2004. Sacred and Secular. Cambridge: Cambridge University Press.

PBS. 2010. God in America. http://www.pbs.org/godinamerica/, accessed September 10, 2011.

Phillips, Kevin. 2006. American Theocracy. New York: Penguin.

Posner, Sarah. 2008. God's Profits. Sausalito, CA: PoliPointPress.

Sears, Alan, and Craig Osten. 2003. The Homosexual Agenda. Nashville, TN: B\&H Books.

Shibley, Mark. 1991. The Southernization of American Religion: Testing a Hypothesis. Sociological Analysis 52:159-174.

Smith, A.M. 2007. Welfare Reform and Sexual Regulation. Cambridge: Cambridge University Press.

Smith, Oram P. 1997. The Rise of Baptist Republicanism. New York: New York University Press.

Snay, Mitchell. 1989. American Thought and Southern Distinctiveness. Civil War History 35(4):311-328. 
Snay, Mitchell. 1993. Gospel of Disunion. Chapel Hill: University of North Carolina Press.

Wildman, Sarah. 2004. Wedding-Bell Blues. Prospect, December.

Williams, Daniel. 2010. God's Own Party. Oxford: Oxford University Press.

Wilson, Angelia R. 2009. Jesus is Their Health Care Provider. The Guardian Comment is Free, http://www.guardian.co.uk/commentisfree/cifamerica/2009/oct/01.

Wilson, Angelia R., and Cynthia Burack. 2012. Where Liberty Reigns and God is Supreme. New Political Science.

Wilson, Angelia R. 2013, forthcoming. Why Europe is Lesbian and Gay Friendly (and why America never will be). Albany: State University of New York.

Zernike, Kate. 2010. Bush Aide? No Bombshell in Age of Fiscal Cares. New York Times, August 26, http://www.nytimes.com/2010/08/27/us/politics/27mehlman.html?ref= kenmehlman. 